\title{
ВПЛИВ НАВЧАЛЬНО-ВИХОВНОГО ПРОЦЕСУ НА АКТУАЛІЗАЦІЮ ЕКОЛОГІЧНОГО ПОТЕНЦІАЛУ МАЙБУТНІХ ФАХІВЦІВ 3 СОЦІАЛЬНОЇ РОБОТИ
}

УдК: 159.92

\section{Паламарчук Ольга Миколаӥвна}

Доктор психологічних наук, дочент, дочент кафедри психології та соияіальної роботи, Вінницький державний педагогічний університет імені М. Коиюбинського, м. Вінниця (Украӥна)

\begin{abstract}
Анотація. У статті розкривається суть та особливості професійної підготовки майбутніх фахівців з сочіальної роботи. Розглядаються ключові аспекти феномену екологічного потенціалу особистості майбутнього фахівия з соиіальної роботи. Охарактеризовано структуру екологічного потенціалу особистості студента. Розкрито особливості впливу навчально-виховного процесу на актуалізацію екологічного потенціалу майбутніх фахівців 3 сочіальної роботи. Встановлено змістові взаємозв'язки між компонентами еколого-професійної підготовки майбутніх фахівців з соиіальної роботи та їхніми еколого-професійними якостями, між різними групами професійно значущуих якостей і окремими еколого-професійними якостями. Визначено основні програмні заходи «Еколого-професійного становлення майбутнього фахівия 3 соиіальної роботи». Описано можливості відкриття в собі майбутніми фахівцями з соціальної роботи нових зон найближчого самовдосконалення особистісних еколого-професійних характеристик $і$ навичок на иляху власного саморозвитку. Представлено результати аналізу рівня актуалізації екологічного потенціалу після запровадження програмних заходів.
\end{abstract}

Ключові слова: екологічний потениіал, особистість майбутнього фахівия, професійна підготовка, екологізація суспільної свідомості.

Постановка проблеми. Загальна динаміка й інтенсивність змін, що відбуваються в навколишньому середовищі, висуває нові вимоги до професійної діяльності в будь-якій галузі. Особливий акцент у процесі професійної діяльності необхідно робити на встановленні зв'язку та поясненні інноваційної поведінки з позиції екологічно орієнтованого спо- собу життя. 3 огляду на це, актуальною є проблема підготовки особистості майбутнього фахівця з соціальної роботи до екологічно орієнтованого способу життя.

Світ ставить перед особистістю сучасного фахівця 3 соціальної роботи безліч екологічних виборів, проблем, ситуацій, в яких необхідно прийняти «правильне» екологічне 
рішення, спираючись на сформовану в ході особистісно-професійного розвитку систему внутрішніх екологічних принципів, екологічних переконань і цінностей. Підготовка фахівців $з$ соціальної роботи до екологічно орієнтованого способу життя $\epsilon$ важливою умовою подолання сучасних екологічних проблем, що існують у нашому суспільстві. У цьому сенсі, необхідним та актуальним у вирішенні проблем екологічного саморозвитку, екологічного самовдосконалення, орієнтації на екологічні способи діяльності у сфері соціальної роботи, ми вбачаємо вивчення екологічного потенціалу особистості майбутнього фахівця з соціальної роботи.

Аналіз останніх досліджень та публікацій. Окреслена тематика знайшла своє відображення у дослідженнях зарубіжних та вітчизняних науковців. Зокрема, науковопрактичні аспекти фахової підготовки майбутніх фахівців з соціальної роботи висвітлені у працях Н. Горішної, І. Звєрєвої, А. Капської, О. Карпенко, А. Панасюка, В. Шепель та інших. Питанням формування фахівця з соціальної роботи як професіонала та розвитку мотиваційної сфери присвячені роботи В. Бочарової, А. Капської, I. Козубенко, А. Ляшенко, В. Поліщук, В. Тименко. Однак, привертає увагу відсутність концептуальних підходів, які дозволили б різнобічно дослідити феномен екологічного потенціалу майбутніх фахівців з соціальної роботи; мала кількість експериментально-психологічних робіт, які розкривають роль екологічного потенціалу в різних видах професійної діяльності [5; 7].

Необхідно зазначити, що дослідження поняття «потенціал» не вийшли за рамки постановки проблеми. У психологічній літературі існує два близьких за змістом поняття «людський потенціал» і «особистісний потенціал», причому досить часто вони ототожнюються, незважаючи на те, що друге значно ширше першого. Н. Байков [1] та В. Марков [6] у поняття «людський потенціал» включають поняття «особистісного потенціалу», що представляє міру розвиненості здатностей особистості та можливостей їх реалізації. Важливою складовою особистісного потенціалу науковці вбачають екологічний потенціал. У майбутніх фахівців з соціальної роботи екологічний потенціал необхідно розвивати через формування у них «екологізму», високого рівня екологічної самосвідомості та екологічної культури, особистісних екологічно важливих якостей.

Виклад основного матеріалу. У рамках вивчення розвитку екологічного потенціалу особистості майбутнього фахівця з соціальної роботи доцільним є 3'ясування суті екологічного потенціалу у найзагальнішому його значенні. Термін «потенціал» використовується у психології для позначення сукупності наявних засобів і можливостей у певній галузі діяльності. Це можливості окремої особистості, групи людей або всього людства, які можуть бути використані 3 метою вирішення конкретного завдання або комплексу задач. 
Поняття «потенціал» як психологічний феномен, інтегрально описує феномени мотивів $\mathrm{i}$ здібностей. Здібності індивіда відображають в цьому випадку вже реалізований потенціал, а мотивація особистості визначає подальші перспективи розвитку потенціалу (нереалізована частина потенціалу).

Структура екологічного потенціалу майбутніх фахівців з соціальної роботи визначається, по-перше, екологічними здібностями молодої людини, по-друге, набором суб'єктивних екологічних можливостей і об’єктивних екологічних умов для реалізації конкретного виду професійної діяльності, по-третє, практичними екологічними навичками особистості. Екологічний потенціал реалізується за допомогою певних екологічних стратегій і технологій їх здійснення. Екологічні стратегії припускають системне екологічне конструювання та екологічне моделювання молодою людиною власного життя. Вони пов'язані 3 екологічними цінностями, екологічними установками, екологічною спрямованістю, смисло-життєвими екологічними орієнтаціями, життєво-екологічними планами i слугують керівництвом до екологічних дій. Технології реалізації екологічного потенціалу $є$ апробованими схемами практично-екологічних дій, спрямованими на задоволення базових потреб майбутніх фахівців з соціальної роботи відповідно до їхніх життєвих планів і перспектив.

Таким чином, в структурі особистості майбутнього фахівця з соціальної роботи, еко- логічний потенціал постає як суб'єктивна система, в якій особливим чином упорядковані внутрішні та зовнішні екологічні ресурси, що забезпечують різноманіття можливих векторів екологічного розвитку і екологічної трансформації особистості в процесі іiї життєвого шляху. Під екологічними ресурсами розуміється набір екологічних засобів, які можуть бути задіяні майбутнім фахівцем з соціальної роботи для досягнення певної екологічної мети або отримання певних екологічних результатів. Змістовна сторона екологічного потенціалу включає в себе такі складові як ступінь екологічної активності, рівень засвоєної екологічної культури, сукупність екологічних знань, умінь, навичок професійного і побутового характеру, сукупність особистісних екологічних якостей, i, найголовніше, рівень духовно - екологічного розвитку особистості майбутнього фахівця з соціальної роботи.

Екологічний потенціал, як і розвиток особистості в цілому не може розглядатися поза конкретним навчально-виховним процесом, тобто екологічний потенціал майбутніх фахівців з соціальної роботи постає як індивідуальна система, напряму пов'язана із специфікою підготовки майбутніх фахівців до професійної діяльності. Професійна екологічноорієнтована підготовка майбутніх фахівців 3 соціальної роботи передбачає:

- $\quad$ внесення змін у зміст та форми навчання, які б були спрямованими на закріплення потрібної для фахової діяльності, 
в умовах екологічної кризи, особистісної екологічної позиції;

- $\quad$ розробку розвиваючих технологій екологічного становлення майбутніх фахівців 3 соціальної роботи.

Процес розробки програмних заходів екологічного становлення майбутніх фахівців 3 соціальної роботи може бути орієнтований на три основні шляхи: впливи, що трансформують смисли свідомості становлення майбутніх фахівців з соціальної роботи; утворення нових форм навчально-професійної діяльності, які також своїми наслідками трансформують діяльність і свідомість, і найкращий третій - еколого-розвиваючі інновації навчальнопрофесійної діяльності і свідомості в нерозривній єдності. У зв'язку 3 цим навчальнопрофесійна діяльність перетворюється на предмет цілеспрямованого проектування, в рамках якого створюються такі засоби ії здійснення, вдаючись до яких, свідомість і діяльність майбутніх фахівців 3 соціальної роботи стають оптимальними і розвиваються згідно 3 поставленими цілями особистісно-екологічного зростання.

Вивчення підходів вчених щодо проектування моделей підготовки фахівців, методики й техніки їх реалізації (I. Вітенко, І. Габа, Р. Габдрєєв, Н. Свдокимова [3], І. Жданов, Л. Карамушка, О. Кобзар, Л. Овсянецька, Л. Орбан-Лембрик, В. Параніч, . Паригін, Н. Пов'якель, А. Ткаченко, В. Рибалка, Ю. Швалб, В. Шторф [4] та ін.) дає можли- вість розробити програму «Екологопрофесійного становлення майбутніх фахівців з соціальної роботи». Необхідність створення такої програми зумовлена не лише потребою продемонструвати компоненти екологопрофесійної підготовки та значущі екологопрофесійної якості у вигляді сукупності, але й встановити змістові взаємозв'язки між компонентами еколого-професійної підготовки та еколого-професійними якостями, між різними групами професійно значущих якостей і окремими еколого-професійними якостями. В основу цієї програми покладено наступні принципові положення:

- особистісно-орієнтований підхід, який забезпечить еколого-професійний розвиток та еколого-професійний саморозвиток особистості майбутнього фахівця 3 соціальної роботи, виходячи із з'ясування індивідуальних особливостей як суб'єкта пізнавальної та предметної діяльності;

процес еколого-професійної підготовки надасть кожному майбутньому фахівцю 3 соціальної роботи можливість реалізувати себе в екологічному пізнанні, екологічній діяльності та поведінці, спираючись на здібності, схильності, інтереси та суб'єктний досвід;

зміст еколого-професійної підготовки, іiі засоби та методи добираються та організовуються так, щоб майбутній фахівець 3 соціальної роботи міг проявити вибірко- 
вість до екологічного матеріалу, його виду та форми;

- $\quad$ критеріальна база еколого-професійної підготовки враховує не тільки рівень досягнутих екологічних знань, умінь і навичок, але й певну сформованість еколого-професійного інтелекту (здібності, якості, характер прояву);

- еколого-професійна обізнаність як сукупність знань, умінь та індивідуальних здібностей $\epsilon$ найважливішим засобом становлення еколого-професійної свідомості майбутнього фахівця $з$ соціальної роботи;

- еколого-професійна грамотність та еколого-професійна освіченість не тотожні за своєю природою. Еколого-професійна грамотність через оволодіння екологічними знаннями, вміннями та навичками забезпечує соціальну та професійну адаптацію в суспільстві. Екологопрофесійна освіченість формує індивідуальне екологічне сприйняття світу, можливість його творчого перетворення, широке використання суб'єктного екологічного досвіду в інтерпретації та оцінці фактів, подій, явищ на основі особистісно-значущих екологічних цінностей та внутрішніх установок;

- традиційні освітні підходи не можуть бути провідними у програмі «Проектування психологічних засобів еколого-професійного розвитку майбут- нього фахівця з соціальної роботи». Значущими стають ті складові, які розвивають екологічну індивідуальність особистості майбутнього фахівця з соціальної роботи, створюють усі необхідні умови для його екологічного саморозвитку та екологічного самовираження;

- $\quad$ еколого-професійна підготовка будується на принципі варіативності, тобто визнання різноманіття змісту та форм екологічного розвитку, вибір яких повинен здійснюватися 3 урахуванням кожного майбутнього фахівця з соціальної роботи, його психологічної підтримки у пізнавальному процесі, складних життєвих обставинах.

В основі програми «Екологопрофесійного становлення майбутнього фахівця з соціальної роботи» лежить забезпечення цілеспрямованого впливу з метою створення $\mathrm{i}$ реалізації сприятливих умов для формування екологічного професіоналізму майбутніх фахівців 3 соціальної роботи у процесі фахової підготовки. Програма грунтується на принципах добровільності та мотивованої участі; системності та наочності; реалізації партнерських взаємин; усвідомлення та рефлексивного переживання; проблемності; професійної спрямованості; науковості та доступності. Психолого-педагогічними умовами запровадження такої програми є створення рефлексивного середовища, яке б сприяло усвідомленню необхідності формування екологічного професі- 
оналізму у майбутніх фахівців 3 соціальної роботи і втілення у відповідні мотиви еколого -професійної діяльності; розвиток і прояв у майбутніх фахівців з соціальної роботи особистісних екологічних якостей, які сприяють оволодінню ними основними компонентами екологічного професіоналізму, стимулювання в них прагнення до підвищення та реалізації еколого-професійних здібностей завдяки внутрішнім сутнісним моральним установкам [9]. Процес еколого-професійної підготовки набуває ефективності, якщо побудований так, що в ньому екологічний професіоналізм вважається головною цінністю і результатом підготовки майбутніх фахівців з соціальної роботи; фахова екологічна підготовка майбутніх фахівців 3 соціальної роботи повинна відбуватися в умовах налагодження духовної взаємодії психологів, викладачів та молоді, що сприятиме створенню доброзичливого психологічного клімату, атмосфери інтелектуальної співтворчості, суб' єкт-суб' єктній взаємодії, творчій активності всіх учасників.

Метою програми «Екологопрофесійного становлення майбутніх фахівців 3 соціальної роботи» є організація і забезпечення процесу проектування інноваційних психологічних засобів еколого-професійного розвитку молоді з подальшою апробацією у процесі навчально-професійної підготовки фахівців.

Основними завданнями для досягнення цілей програми є: визначення методологічних проблем психолого-педагогічної практики в процесі еколого-професійної підготовки майбутніх фахівців з соціальної роботи; формулювання організаційних, соціально-психологічних і психологопедагогічних вимог до екологопрофесійного розвитку майбутніх фахівців з соціальної роботи;

проектування форм психологопедагогічнтої практики у сфері розвитку еколого-професійних інтересів молоді; вироблення критеріїв ефективності психолого-педагогічних засобів екологопрофесійного розвитку майбутніх фахівців;

верифікація розроблених психологопедагогічних засобів екологопрофесійного розвитку майбутніх фахівців з соціальної роботи;

створення організаційної моделі еколого -професійної підготовки фахівців 3 метою вироблення у них стратегій і технологій еколого-професійної діяльності;

спрямування психолого-педагогічної діяльності фахівців у сфері екологопрофесійної підготовки на задоволення еколого-професійних інтересів майбутніх фахівців з соціальної роботи;

впровадження інноваційних психологопедагогічних технологій у практику діяльності провідних фахівців (організаційно-діяльнісних ігор, ділових 
ігор, тренінгів тощо);

- $\quad$ конструювання програми психологічного тренінгу формування екологопрофесійних цінностей майбутніх фахівців з соціальної роботи та розвитку їхніх еколого-професійних інтересів; забезпечення процесу освоєння провідними фахівцями у сфері еколого-поофесійної підготовки інноваційних психологопедагогічних технологій екологопрофесійного розвитку;

- $\quad$ створення психолого-педагогічних умов для повноцінної реалізації особистого екологічного потенціалу учасників програми;

- психологічний супровід впровадження проектів, передбачених цією програмою.

Основними програмними заходами є:

- створення організаційного проекту екологічного становлення майбутніх фахівців $з$ соціальної роботи. В основі даного проекту лежить можливість задоволення особистісних інтересів через наявність екологічної складової у їхній діяльності;

- організація та проведення науковометодичних семінарів 3 розробки та запровадження в процес підготовки майбутніх фахівців з соціальної роботи інноваційних психологічних засобів, що сприяють їхньому екологічному становленню;

- тренінг-семінар для викладачів ЗВО «Психологічні засоби самовдосконален- ня і реалізації творчого потенціалу особистості викладача у сфері впровадження інноваційних технологій екологічного розвитку в освітній процес ЗВО»;

- $\quad$ апробація психолого-педагогічних засобів екологічного становлення майбутніх фахівців з соціальної роботи;

конструювання та апробація програми еколого-психологічного тренінгу реалізації екологічного потенціалу майбутніх фахівців з соціальної роботи;

- організаційно-діяльнісна гра «Проектування еколого-орієнтованої життєдіяльності майбутніх фахівців 3 соціальної роботи»;

- $\quad$ конкурс студентських наукових проектів «Сфера перспективної екологопрофесійної діяльності».

Зупинимось більш детально на конструюванні та апробації програми екологопсихологічного тренінгу реалізації екологічного потенціалу майбутніх фахівців 3 соціальної роботи. Еколого-психологічний тренінг у рамках підготовки майбутніх фахівців з соціальної роботи являв собою комплексну форму еколого-професійної освіти, засновану на загальній методології соціально-психологічних тренінгів, спрямовану на корекцію і розвиток відносин фахівця 3 навколишнім природним середовищем. Еколого-психологічний тренінг дозволяє вирішувати наступні завдання: розширення індивідуального екологопрофесійного простору, формування у майбу- 
тніх фахівців 3 соціальної роботи здатності відчувати себе частиною природи; формування позитивного еколого-професійного погляду на себе і навколишній світ у цілому; корекція і формування цілей еколого-професійної взаємодії фахівця з природними об'єктами [8, с.7].

Чітко організована, цілеспрямована робота з використанням еколого-психологічного тренінгу дозволяє використовувати додатковий матеріал, який розширює природоохоронний еколого-професійний світогляд і конкретизує еколого-професійні знання. Спостереження й аналіз майбутніми фахівцями з соціальної роботи реального еколого-професійного життя в процесі роботи дозволяє їм робити висновки про стан навколишнього середовища, намічати конкретні програми екологопрофесійних дій, отримувати уроки на майбутнє, змінювати мету своєї професійної діяльності і професійну поведінку в довкіллі відповідно до законів природи [2, с. 6 ].

На думку Е. Гриньової, метою екотренінгу є формування «екологічного почуття», почуття співпричетності до всього живого, усвідомлення планети Земля «спільним домом», створення певного «блокування» скоєння екологічних помилок як у майбутній соціальній діяльності, так і в побуті, прищеплення етичної і моральної відповідальності перед кожною живою істотою, будь то рослина чи тварина. Крім того, заняття екотренінгом дають помітний оздоровчий ефект, знімають психологічну напругу і налаштовують на доб- розичливе ставлення до всього живого. Позитивний емоційний фон занять допомагає знімати стреси й агресивність, викликані відірваністю від природного середовища і вимушеним проживанням в «кам'яних джунглях». Хочеться звернути увагу на те, що до екотренінгу необхідно поставитися саме як до тренінгу, а не як до пояснення будь - яких правил.

Еколого-психологічний тренінг, як зазначають С. Дерябо та В. Ясвін, базується на методології соціально-психологічного тренінгу. Даний тренінг включає комплекс вправ, спрямованих на вирішення наступних завдань: корекцію, формування і розвиток екологічних установок особистості, передусім, подолання антропоцентричного, прагматичного ставлення до природних об'єктів; корекцію цілей взаємодії особистості майбутнього фахівця з соціальної роботи з природними об'єктами; навчання умінням і навичкам такої взаємодії; розвиток перспективних можливостей майбутнього фахівця з соціальної роботи при його контакті з природними об'єктами; розширення індивідуально-екологічного простору зони персональної відповідальності за природу $[10$, с. 80$]$.

Тренінг являв собою тижневий курс по 2,5-3 години в день. Проведення тренінгу протягом декількох днів підряд дозволило розвинути, відпрацьовувати і відточити екологопрофесійні якості та навички майбутніх фахівців 3 соціальної роботи в режимі реального 
часу шляхом отримання досвіду в дії та безпосередній діяльності. У процесі проведення тренінгу використовувалась наступна стратегія. На початку пропонувалися вправи та ігри, спрямовані на розширення перцептивного досвіду взаємодії майбутніх фахівців з соціальної роботи з природою; потім - на формування екологічної емпатії, стимулювання ідентифікації з природними об'єктами. Це створювало психологічну основу i готовність до освоєння компетентних технологій взаємодії майбутніх фахівців з соціальної роботи 3 природними об'єктами, чому присвячений наступний етап тренінгу. У заключній частині використовувалися вправи та ігри узагальнюючого характеру, які спрямовані на корекцію стратегії взаємодії з природними об'єктами, екологізацію світогляду майбутніх фахівців з соціальної роботи, розширення суб'єктивного екологічного простору, створення суб'єктсуб'єктних відносин тренера та учасників. Більшість запропонованих вправ не вимагає спеціального матеріального забезпечення і може проводитися у звичайних умовах, хоча ефект від тренінгу вище, якщо він проходить в умовах відповідним чином організованого освітнього середовища.

Методичні особливості організації даної роботи полягали в тому, що майбутнім фахівцям з соціальної роботи пропонувалося за обмежений час виконати нестандартні завдання у творчій формі. Еколого-психологічний тренінг було сконструйовано як систему коре- кційно-педагогічних прийомів, кожен 3 яких ініціював, актуалізував дію певного психологічного механізму розвитку суб'єктивного ставлення майбутніх фахівців з соціальної роботи до природи. Еколого-психологічний тренінг являє собою конкретну модель «педагогічної кальки», яка накладається на «психологічну матрицю», моделюючу систему психологічних механізмів розвитку суб'єктивного ставлення майбутніх фахівців з соціальної роботи до природи. Головним завданням було створення емоційно-інтелектуального простору для ініціативи майбутніх фахівців 3 соціальної роботи.

У результаті активного психологічного впливу, здійснюваного в ході тренінгу, вдалося актуалізувати внутрішній особистісний потенціал майбутніх фахівців з соціальної роботи і досягти глибинного налаштування на вдосконалення індивідуальних екологопрофесійних цінностей в інтересах досягнення успіху в майбутній еколого-професійній діяльності; сформувати правильні уявлення про психологічні механізми взаємовпливу і взаємодії майбутніх фахівців з соціальної роботи та природного середовища. Як наслідок, змінилися уявлення майбутніх фахівців з соціальної роботи про те, що таке екологопрофесійна діяльність, якими якостями повинні володіти ефективні їі учасники. У підсумку проявилася позитивна динаміка в бік ступеня усвідомлення майбутніми фахівцями 3 соціальної роботи своєї ролі у формуванні взаємин 
в системі «особистість-природне середовище» та подолання психологічних бар'єрів, що заважають прояву тих чи інших екологопрофесійних якостей.

У процесі проведення тренінгу акцент було зроблено на реалізації учасниками нового екологічного досвіду, відкритті ними в собі нових зон найближчого самовдосконалення особистісних еколого-професійних характеристик і навичок на шляху саморозвитку себе як суб'єкта діяльності. Це, в свою чергу, призвело до розширення діапазону екологоповедінкових стратегій, що застосовуються в ситуаціях професійної діяльності фахівців 3 соціальної роботи, усвідомлення екологосоціальної місії, розуміння відповідальності за будь-який професійний вибір, прийняття рішень більш повно реалізовувати свій екологопрофесійний потенціал.

Впровадження даного програмного заходу сприяло актуалізації екологічного потенціалу особистості майбутнього фахівця з соціальної роботи, тобто забезпечило подолання розриву між екологічними знаннями та еко- логічною діяльністю; розвитку екологоорієнтованого типу свідомості у майбутніх фахівців з соціальної роботи, який проявиться в екологічній діяльності, що, на нашу думку, стане основою екологічного способу їхнього життя.

До запровадження програмних заходів рівень актуалізації екологічного потенціалу був суттєво нижчим. Після використання програмних заходів рівень актуалізації екологічного потенціалу у фахівців з соціальної роботи помітно зріс. Нами було проведено вимірювання рівня актуалізації екологічного потенціалу одразу після запровадження заходів та через місяць. Динаміка показника ефективності запропонованих програмних заходів представлена в таблиці 1.

Для перевірки статистичної гіпотези у даному випадку ми застосовували $t-$ критерій Стьюдента з 96 ступенями волі для показника рівня актуалізації. В результаті було зафіксовано вихід статистики за критичні рівні розподілу $t=3,09$ при критичному теоретичному значенні 2,625 на рівні значущості $\rho<0,01$.

Таблиияя 1.

\section{Ефективність програмних заходів}

\begin{tabular}{|c|c|c|c|}
\hline Рівень інноваційності & $\begin{array}{c}\text { Кількість досліджу- } \\
\text { ваних }\end{array}$ & $\begin{array}{c}\text { Середній показник } \\
\text { інноваційності до вико- } \\
\text { ристання програмних } \\
\text { заходів }\end{array}$ & $\begin{array}{c}\text { Середній показник } \\
\text { інноваційності після } \\
\text { програмних заходів }\end{array}$ \\
\hline Контрольна група & 50 & & 12,8 \\
\hline $\begin{array}{c}\text { Експериментальна група (одразу } \\
\text { після програми) }\end{array}$ & 48 & 12,6 & 16,3 \\
\cline { 1 - 2 } $\begin{array}{c}\text { Експериментальна група (через } \\
\text { 1 місяць після програми) }\end{array}$ & 44 & & 15,4 \\
\hline
\end{tabular}


Отже, можна стверджувати, що розроблена авторська програма «Екологопрофесійного становлення майбутніх фахівців 3 соціальної роботи» мала позитивний ефект. Результати психолого-діяльнісного проектування екологічних уявлень фахівців з соціальної роботи в моделі професійного майбутнього, підкреслюють необхідність і важливість актуалізації екологічного потенціалу та здатність і готовність суб'єктів діяльності до самостійності прийняття екологічних рішень; екологічної відповідальності перед теперішніми та майбутніми поколіннями.

Висновки. Актуалізація екологічного потенціалу особистості майбутнього фахівців 3 соціальної роботи пов'язана 3 виникненням потреби в еколого-професійному саморозвитку та еколого-професійному рості. В основі актуалізації екологічного потенціалу особистості майбутнього фахівця з соціальної роботи має лежати формування екоцентричного типу екологічної свідомості, тобто система уявлень про світ та професію, для якої характерні: орієнтація на екологічну доцільність, відсутність протиставлення людини і природи; сприйняття природних об'єктів як рівноправних суб'єктів; баланс прагматичної і непрагматичної взаємодії з природою. Взаємодія майбутнього фахівця з соціальної роботи зі світом природи у процесі професійної діяльності має значний психолого-екологічний потенціал, який охоплює психофізіологічні, психотерапевтичні, реабілітаційні, естетичні, когнітивні, комуні- кативні, вчинкові і самореалізаційні функції. Такий діапазон впливу перетворює цей потенціал на фактор загального екологічного формування і розвитку особистості, екологічного становлення особистості майбутнього фахівця 3 соціальної роботи.

\section{Перелік використаних джерел:}

1. Байков Н. М. Молодежный потенциал региона: опыт социологического анализа / Н. М. Байков, Ю. В. Березутский, Е. В. Буката. - Хабаровск: ДВАГС, 2001. - С. 34.

2. Давыдова E. B. Измерение качества жизни / Е. В. Давыдова, А. А. Давыдов. - М. : Изд. РАН, 1993. -52 c.

3. Свдокимова Н. О. Компетентність як універсальна психологічна передумова професійної підготовки у ВНЗ / Н. О. Свдокимова // Актуальні проблеми психології: зб. наукових праць / Інститут психології ім. Г. С. Костюка АПН України / за ред. С.Д. Максименка. - Т.7: Екологічна психологія. - Вип.17: Психологія освітнього простору. - Миколаїв: ТОВ «Фірма «ліон», 2008. - С. 237-242.

4. Габа I. M. Освітне середовище: соціальнопсихологічна парадигма / І. М. Габа // Актуальні проблеми психології: зб. наук. пр. Ін-ту психології імені Г. С. Костюка АПН України ; за ред. С. Д. Максименка. - К., 2010. - Т. 7; вип. 22. - С.27-31.

5. Маноха I. П. Потенціал індивідуального буття людини: поняття, сутність, способи тлума-чення / І. П. Маноха // Вісник Київського університету ім. Т.Шевченка; Серія: Соціологія. Психологія. Педагогіка. - К.: Ред.вид. центр «Київ. ун-т», 1998. - Вип. 5. - С.23-27.

6. Марков B. Н. Личностно-профессиональный потенциал управленца и его оценка / В. Н. Марков. - М. : РАГС, 2001.

7. Моляко В. О. Психологічні дослідження творчого 
потенціалу особистості: монографія / В.О. Моляко. К. : Педагогічна думка, 2008. - 208 с.

8. Перфилова О. Е. Развитие социально-экологической компетентности педагога в профессиональном образовании /автореф. дисс...к.п.н. / О. Е. Перфилова. - М., 2007.

9. Шульга Г. Б. Конфліктологічна компетентність як особистісна передумова формування екологічності педагогічної взаємодії у професійній діяльності майбутнього вчителя / Г. Б. Шульга // Актуальні проблеми психології: Збірник наукових праць Інституту психології імені Г.С. Костюка НАПН України. - Житомир: «Видво ЖДУ ім. І. Франка», 2016. - Том VII. Екологічна психологія. - Випуск 41. - С. 460-468.

10. Ясвин В. А. Методики диагностики и коррекции отношения к природе. Серия экологическая психология и педагогика / В. А. Ясвин, С. Д. Дерябо. - М. : Просвещение, 1996. - 141 с.

\section{References (Transliteration):}

1. Baykov N. M. Molodezhnyiy potentsial regiona: opyit sotsiologicheskogo analiza / N. M. Baykov, Yu. V. Berezutskiy, E. V. Bukata. - Habarovsk: DVAGS, 2001. S. 34.

2. Davyidova E. V. Izmerenie kachestva zhizni / E. V. Davyidova, A. A. Davyidov. - M. : Izd. RAN, 1993. - 52 s. 3. Evdokimova $N$. O. Kompetentnist yak universalna psihologichna peredumova profesIynoii pIdgotovki u VNZ / N. O. Evdokimova // Aktualni problemi psihologiyi: zb. naukovih prats / Institut psihologiyi Im. G. S. Kostyuka APN Ukrayini / za red. S.D. Maksimenka. - T.7: Ekologichna psihologiya. - Vip.17: Psihologiya osvitnogo prostoru. - Mikolayiv: TOV «Firma «Ilion», 2008. - S. 237 -242 .

4. Gaba I. M. Osvitne seredovische: sotsailnopsihologichna paradigma / I. M. Gaba // Aktualni problemi psihologiyi: zb. nauk. pr. In-tu psihologiyi imeni G. S. Kostyuka APN Ukrayini ; za red. S. D. Maksimenka. - K., 2010. - T. 7; vip. 22. - S.27-31.
5. Manoha I. P. Potentsial Individualnogo buttya lyudini: ponyattya, sutnist, sposobi tlumachennya / I. P. Manoha // Visnik Kiyivskogo universitetu im. T.Shevchenka; Seriya: Sotsiologiya. Psihologiya. Pedagogika. - K.: Red.-vid. tsentr «Kiyiv. un-t», 1998. - Vip. 5. - S.23-27.

6. Markov $V . \quad N$. Lichnostno-professionalnyiy potentsial upravlentsa i ego otsenka / V. N. Markov. - M. : RAGS, 2001.

7. Molyako V. O. PsihologIchnI doslIdzhennya tvorchogo potentsIalu osobistostI: monografIya / V.O. Molyako. - K. : PedagogIchna dumka, 2008. - 208 s.

8. Perfilova O. E. Razvitie sotsialno-ekologicheskoy kompetentnosti pedagoga $\mathrm{v}$ professionalnom obrazovanii / avtoref. diss...k.p.n. / O. E. Perfilova. - M., 2007.

9. Shulga G. B. KonflIktologIchna kompetentnIst yak osobistIsna peredumova formuvannya ekologIchnostI pedagogIchnoYi vzaEmodIYi u profesIynIy dIyalnostI maybutnogo vchitelya / G. B. Shulga // AktualnI problemi psihologIYi: ZbIrnik naukovih prats Institutu psihologIYi ImenI G.S. Kostyuka NAPN UkraYini. - Zhitomir: «Vid-vo ZhDU Im. I. Franka», 2016. - Tom VII. EkologIchna psihologIya. - Vipusk 41. - S. 460-468.

10. Yasvin $V$. A. Metodiki diagnostiki i korrektsii otnosheniya k prirode. Seriya ekologicheskaya psihologiya i pedagogika / V. A. Yasvin, S. D. Deryabo. - M. : Prosveschenie,1996. - 141 s.

\section{Palamarchuck Olga}

Doctor of psychological sciences, Associate Professor, Associate Professor department of psychology and social work of Mykhaylo Kotsybynskiy Vinnytsia State Pedagogical University, Vinnitsia (Ukraine)

\section{INFLUENCE OF THE EDUCATIONAL - EDUCATOR PROCESS ONACTUALIZATION OF ECOLOGICAL POTENTIAL OF FUTURE SPECIALISTS ON SOCIAL WORK}

\section{ABSTRACT}

The article is devoted to the research of the influence of the educational process on actual- 
ization of the environmental potential of future specialists in social work. The meaning of the professional work of social work specialists in the context of transformational social change is to establish communication and explain innovation behavior from the standpoint of an environmentally-oriented way of life. The formation of a conceptual approach to the environmentally oriented activity of a social work specialist is based on the fact that modern activity is a peculiar form of human behavior, which is based on the actualization of the ecological potential; assuming responsibility for the consequences of the activity, readiness for making environmental decisions; the focus on the active transformation of the surrounding world.

The developed program «Environmental formation of the future specialist in social work» is based on the creation of a reflexive environment, which would contribute to the awareness of the need for the formation of environmental professionalism among future specialists in social work and the implementation of appropriate motives of environmental and professional activities. This concept is based on the actualization of the environmental potential of future social work specialists, which will help them to master the main components of environmental professionalism; stimulating their desire to improve and implement ecological-professional abilities.

It is shown that the most productive approach to the problem of actualization of the environmental potential of the personality of the future specialists in social work is systematic methodology with the leading position of unity of consciousness and activity. In this regard, the importance of the ecologically-innovative direction of professional activity, which involves the creation and implementation of various types of environmental innovations, which will cause changes in the activities of a specialist in social work in general, and in his person in particular. It is proved that updating of ecological potential is based on gradual advancement of future specialists in social work in understanding of own ecological responsibility and formation of ecological self-control in practical activity.

Keywords: ecological potential, personality of the future specialist, professional training, ecologization of social consciousness.

\section{Паламарчук Ольга Николаевна}

Доктор психологических наук, доиент, доиент кафедры психологии и сочиальной работьл, Винничкий государственный педагогический университет имени М. Коцюбинского, Винница (Украина)

\section{ВЛИЯНИЕ УЧЕБНО- ВОСПИТАТЕЛЬНОГО ПРОЦЕССА НА АКТУАЛИЗАЦИЮ ЭКОЛОГИЧЕСКОГО ПОТЕНЦИАЛА БУДУЩИХ СПЕЦИАЛИСТОВ ПО СОЦИАЛЬНОЙ PAБOTE}

Аннотация. Статья посвящена исследованию влияния учебно-воспитательного процесса на актуализацию экологического потенциала будущих специалистов по социальной работе. Смысл профессиональной деятельности специалистов по социальной работе 
в условиях трансформационных общественных изменений заключается в установлении связи и объяснении инновационного поведения с позиции экологически ориентированного образа жизни. Формирования концептуального подхода к экологически ориентированной жизнедеятельности специалиста по социальной работе основывается на том, что современная деятельность это - своеобразная форма человеческого поведения, в основе которой лежит актуализация экологического потенциала; взятие на себя ответственности за последствия деятельности, готовность к принятию экологических решений; направленность на деятельное преобразование окружающего миpa.

Разработана программа «Экологического становления будущего специалиста по социальной работе» основана на создании рефлексивной среды, которая бы способствовала осознанию необходимости формирования экологического профессионализма у будущих специалистов по социальной работе и воплощение в соответствующие мотивы экологопрофессиональной деятельности. Данная концепция строится на актуализации экологического потенциала у будущих специалистов по социальной работе, способствовать овладению ими основными компонентами экологического профессионализма; стимулировании в них стремление к повышению и реализации эколого-профессиональных способностей.

Показано, что наиболее продуктивным подходом к проблеме актуализации экологического потенциала личности будущего специалиста по социальной работе является системотворческая методология с ведущим положением единства сознания и деятельности. В связи с этим, возрастает значение экологоинновационного направления профессиональной деятельности, которая предусматривает создание и внедрение различных видов экологических новшеств, которые повлекут изменения как в деятельности специалиста по социальной работе в целом, так и в его личности в частности. Доказано, что актуализация экологического потенциала основывается на постепенном продвижении будущего специалистов по социальной работе в осознании собственной экологической ответственности и формировании экологического самоконтроля в практической деятельности.

Ключевые слова: экологический потенциал, личность будущего специалиста, профессиональная подготовка, экологизация общественного сознания.

Дата отримання статті: 05.12.2017 Дата рекомендації до друку: 23.12.2017 (C) Паламарчук О. М. 